\title{
Archipel
}

ARCHIPEL Études interdisciplinaires sur le monde insulindien

99 | 2020

Varia

\section{The Women and the Generals: Unraveling a Myth of Sexual Perversion}

\section{Saskia Wieringa}

\section{(2) OpenEdition \\ 12 Journals}

\section{Electronic version}

URL: http://journals.openedition.org/archipel/1642

DOI: 10.4000/archipel.1642

ISSN: 2104-3655

\section{Publisher}

Association Archipel

\section{Printed version}

Date of publication: 15 July 2020

Number of pages: $23-27$

ISBN: 978-2-910513-83-2

ISSN: 0044-8613

\section{Electronic reference}

Saskia Wieringa, "The Women and the Generals: Unraveling a Myth of Sexual Perversion", Archipel [Online], 99 | 2020, Online since 03 June 2020, connection on 15 March 2021. URL: http://

journals.openedition.org/archipel/1642 ; DOl: https://doi.org/10.4000/archipel.1642 
SASKIA WIERINGA ${ }^{1}$

\section{The Women and the Generals: Unraveling a Myth of Sexual Perversion}

The Women and the Generals

Documentary, 56 min., 2013

Director: Maj Wechselmann ${ }^{2}$

Production : Swedish Television (SvT) / Norwegian Broadcasting (NRK) / Fritt Ord (Norway)

Distributed via http://www.wechselmann.se/en/2013/03/26/the-women-andthe-generals/

Language: English/Indonesian with English captions and subtexts

The documentary is also available, via VIMEO, in a longer version (84 min), which is the basis of the present review.

The Women and the Generals by Maj Wechselmann tells the story of the sexual slander fabricated by the Indonesian military under General Suharto which fuelled the campaign to annihilate the Indonesian Communist Party (PKI). The lies center around the presence of women at the site where six generals and one lieutenant were buried in a disused well. They had been abducted and murdered by a group of their own soldiers under the control of junior officers in the night of October 1, 1965. The girls attended a training given by the Air Force in preparation for the anti-Malaysia campaign of

1. Emeritus professor, Amsterdam University.

2. To date the Danish-Swedish director Maj Wechselmann (1942) has produced some 45 films. She became known with her documentary on the defense industry Viggen (1973). 
President Sukarno. The documentary explains how and why the lies have been fabricated, their impact up to nowadays in Indonesia and presents a detailed counter-version based on archival images, victims and expert testimonials.

The military under General Suharto blamed the Indonesian Communist Party (PKI) for the deaths of the high-ranking militaries killed on 1 October. In reality, only a handful of top leaders of the PKI had been involved in planning the abductions, but not the murders, and they had not been involved in the execution of those plans. Members of the leftist women's group Gerwani were accused of having seduced, sexually tortured and killed the generals. This slander forms the core of the propaganda campaign that the army used to incite mainly Muslim mass organizations and militias to assist the army in murdering perhaps one million people and incarcerating hundreds of thousands others. The prisoners were tortured, subjected to sexual violence and many were sent to slave labour camps such as on the island of Buru. The victims were never tried, and the perpetrators of these crimes were never charged. The survivors have lived with the stigma that they were considered 'traitors to the nation' ever since and the women among them have always been associated with sexual perversion.

The consequences of this bloody period in Indonesian history were not only felt by the direct victims. As the documentary film shows, after General Suharto had replaced President Sukarno, and established a military dictatorship, called the 'New Order', progressive social movements such as Gerwani, and the progressive trade unions, (as well as the farmers' union and the leftist cultural association, but this is not detailed here) were destroyed. State-dominated women's organizations were established to turn women into obedient housewives and mothers. Labourers and peasants were likewise controlled to serve the interests of the economic and military power holders.

The false accusations that the action of the 30 September Movement, as the group that abducted and killed the generals called themselves, was masterminded by the PKI and that the Party was preparing to take over the country provided the pretext for General Suharto's seizure of power. They were part of a propaganda campaign staged by Suharto which not only led to one of the worst genocides in history which took place between 1965-1968 but which also helped spread terror to sustain the military dictatorship he established.

A major part of the documentary film The Women and the Generals is a critique of the three hours' infamous propaganda film that President Suharto ordered to be produced. This film is called 'The Betrayal of G30S/PKI', by Arifin C. Noor. It was obligatory for school children to watch it ever since it was released in 1984. The bloody scenes it contains have traumatized millions of school children, as Chika Noya explains in 'The Women and the Generals'. They had this memory of 'communist women' as devilish, cruel whores etched on their minds. 


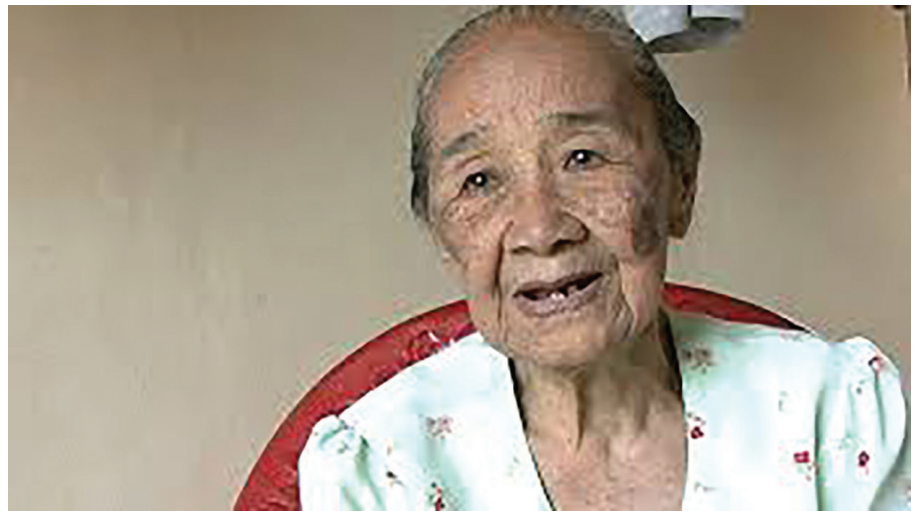

The Women and the Generals

During the New Order writers and artists were compelled to repeat the 'truth' of the army version of the 'events of 1965' and as a critical discussion of this period in Indonesian history was almost impossible the Indonesian people grew up with these distorted ideas. As the prominent historian Hilmar Farid explains in The Women and the Generals, smart students had to uncover the truth of this period themselves. Serious analyses of the army propaganda film and of any aspects related to the mass crimes against humanity by the army and the militias associated with them were prohibited.

To their despair women who had legally and enthusiastically carried out many social, educational and political activities as proud members of the 'socialist family' in Indonesia, and who had been imprisoned for many years under inhuman conditions, came home to find themselves being associated with unspeakable perversions. The memories of their social activism had been supplanted by the fake memories of their alleged perverse acts. To escape the social censorship engineered by these constructed memories, a small group of them lived together in a home in Jakarta, where Maj Wechselmann interviewed them.

The army propaganda film portrays Suharto as the hero who managed to save the nation from murderous and sexually perverse communists. The documentary The Women and the Generals exposes the lies of the propaganda film in which fiction poses as truth and thus reveals the 'hero' of the New Order to be a villain. Wechselmann also uses shots of another propaganda tool of the military regime, the Pancasila Sakti (Holy Pancasila) Monument on the site where the generals were thrown into a well. On this monument, the story of 'The Betrayal of G30S/PKI' is repeated. It became an almost sacred place. During the New Order the vast terrain of the Holy Pancasila Monument used to swarm with children and adults in Muslim dress. Below the huge statues of the murdered generals a bronze mural is placed which depicts the post- 
independence history of Indonesia according to Suharto and which contains depictions of the so called 'dance of the fragrant flowers' which the women present at the site allegedly had danced to seduce and castrate the generals. The museum complex itself comprises a museum and the building in which the generals had been allegedly murdered and mutilated. As John Roosa and Saskia Wieringa explain in The Women and the Generals, the official autopsy demonstrates very clearly the generals were killed by bullets; they were not castrated.

The largest part of the documentary was shot around 2009 and 2010 and contains interviews with women survivors by Maj Wechselmann. They were teachers, journalists, or trade union leaders, heavily traumatized and stigmatized. They spent many years in jail under inhuman conditions and after their release were reduced to poverty. Most of them are no longer alive now, and the interviews provide a rare glimpse into their harrowing experiences. They tell that when they realised the army and the militias went hunting for anyone associated with the left, some of them went on the run, with their children, trying to survive in the jungle. Ultimately all of them were arrested and horribly tortured and raped.

Other former prisoners interviewed for the film include the poet and filmmaker Putu Oka Sukanta and the writer Pramoedya Ananta Toer. Beside these interviews with survivors, academics like John Roosa, Olle Törnquist, Saskia Wieringa and Hilmar Farid as well as human rights activists like Nursyahbani Katjasungkana, Nusya Kuswatin and Chika Noya provide background information. Particularly revealing is the material from the outrageous NBC-film 'The Troubled Victory - The Battle for Asia', which shows both the arrests and murders at the time, and the influence of the CIA on the army. The return of American businesses, some of them previously nationalised by Sukarno, went hand in hand with the destruction of the trade union movement. The documentary also has archival footage from the events of 1965-1968, as well as from the demonstrations and the shootings at Trisakti University that marked the end of the military dictatorship in 1998.

The country is littered with mass graves. The local population usually knows their locations, which have become haunted places, as Nusya Kuswatin explains. She used to live close to one of the largest mass graves, in the Botanical gardens in Purwodadi, East Java. The human rights lawyer Nursyahbani Katjasungkana also lived close by, and as a 10-year old girl she regularly saw the corpses of people murdered in the night, on her way to school. When later she defended one of the victims she was immediately branded as a 'defender of communists'. She was one of the women leaders who spearheaded the protests that led to the fall of General Suharto. The women activists found a soft spot in the General's armour when, in the Asian economic crisis of 1997, food shortages occurred. How come, they mocked him, that a self-styled 'Father of Development' cannot provide milk for the nation's children? 
The film shows some footage of the first exhumation of a mass grave in Wonosobo, carried out by a group of human rights defenders around Mrs Sulami, a former Gerwani leader. Some of the bodies could be identified, but when their families tried to give them a proper reburial, they were attacked by an Islamist mob.

A major part of the documentary is devoted to the difficult search for justice for the victims and an end to the impunity of the survivors. Even after the end of the military regime human rights activists like Munir Said Thalib, who received the Right Livelihood Award in 2000 for his courage, were attacked. He was murdered in 2004. So far the mastermind of this assassination walks free. During the short presidency of the charismatic and progressive Muslim leader Abdurrahman Wahid (1999-2001), popularly called Gus Dur, there was hope Indonesia would confront the truth of this ugly period in its history. History school books were rewritten, in which effort Hilmar Farid was involved. But when they were ready, they were burnt; they never reached the schools they were meant for.

When Wechselmann was shooting her film, the National Commission on Human Rights had started its investigation into the mass crimes against humanity committed after October 1 in Indonesia. A valiant effort, but, she notes, how can seven investigators ever be able to cover such massive and widespread crimes?

The film ends with two telling scenes. Filmmaker Eros Djarot recounts how his team was prevented from shooting his fictional film about a former member of Gerwani who was arrested and tortured. Although he had the permission to shoot, a mob prevented him from doing that. The second episode reports the valiant efforts of family members of students murdered by the army during the 1990 unrest, Munir's widow, survivors of the 1965 events and of other crimes against humanity to get justice for these crimes. Every Thursday afternoon they stage silent demonstration named Kamisan in front of the presidential palace.

In her interviews Wechselmann vividly captures the lasting effects on the memory of the nation of the terror that started with the slander of the girls who watched the generals being killed by the military on their training ground. The value of the film is the combination of these and other interviews, and archival footage. It provides a comprehensive overview of this period, with a focus on the sexual propaganda which formed the core of the campaign which was fabricated to incite the Muslim militia to help murder possibly a million people. This documentary provides a much-needed background to understand the silence and impunity that still reign in Indonesia around the crimes against humanity committed after October 1 1965. The effects of this campaign are still felt in Indonesian society. The Kamisan continue and human rights defenders are still labelled 'communists'. 
